Article

\title{
All Work and No Play? Facilitating Serious Games and Gamified Applications in Participatory Urban Planning and Governance
}

\author{
Cristina Ampatzidou ${ }^{1, *}$, Katharina Gugerell ${ }^{1}$, Teodora Constantinescu ${ }^{2}$, Oswald Devisch ${ }^{2}$, Martina Jauschneg ${ }^{3}$ \\ and Martin Berger ${ }^{3}$ \\ ${ }^{1}$ Department of Spatial Planning \& Environment, University of Groningen, 9747AD Groningen, The Netherlands; E-Mails: \\ c.ampatzidou@rug.nl (C.A.), k.gugerell@rug.nl (K.G.) \\ ${ }^{2}$ Faculty of Architecture \& Arts, Hasselt University, 3590 Diepenbeek, Belgium; E-Mail: teodora.constantinescu@uhasselt.be \\ (T.C.), oswald.devisch@uhasselt.be (O.D.) \\ ${ }^{3}$ Green City Lab Vienna, 1010 Vienna, Austria; E-Mails: office@jauschneg.at (M.J.), martin.kp.berger@tuwien.ac.at (M.B.) \\ * Corresponding author
}

Submitted: 14 November 2017 | Accepted: 22 January 2018 | Published: 29 March 2018

\begin{abstract}
As games and gamified applications gain prominence in the academic debate on participatory practices, it is worth examining whether the application of such tools in the daily planning practice could be beneficial. This study identifies a research-practice gap in the current state of participatory urban planning practices in three European cities. Planners and policymakers acknowledge the benefits of employing such tools to illustrate complex urban issues, evoke social learning, and make participation more accessible. However, a series of impediments relating to planners' inexperience with participatory methods, resource constraints, and sceptical adult audiences, limits the broader application of games and gamified applications within participatory urban planning practices. Games and gamified applications could become more widely employed within participatory planning processes when process facilitators become better educated and better able to judge the situations in which such tools could be implemented as part of the planning process, and if such applications are simple and useful, and if their development process is based on co-creation with the participating publics.
\end{abstract}

\section{Keywords}

citizen engagement; games; gamification; participatory planning; serious games; urban governance; urban planning

Issue

This article is part of the issue "Crowdsourced Data and Social Media for Participatory Urban Planning", edited by Bernd Resch (University of Salzburg, Austria), Peter Zeile (Karlsruhe Institute of Technology, Germany) and Ourania Kounadi (University of Salzburg, Austria).

(C) 2018 by the authors; licensee Cogitatio (Lisbon, Portugal). This article is licensed under a Creative Commons Attribution 4.0 International License (CC BY).

\section{Introduction}

Games and gamified applications are often described as being a magic bullet in current governance debates, with their aim to attract citizens to engage with city matters and planning questions, to participate in decisionmaking, and to improve the overall process of public participation. Public engagement is dominated by conceptual and practical difficulties, it is still framed in the dominant rhetoric of mainly involving the citizens who are 'affected' by the plans, and it takes place within timeframes set by the respective planning procedures and contracting organisation (Horelli, 2002). Thus, an increasing number of people perceive participation as pointless and rarely able to resolve conflicts or influence decisionmaking (Innes \& Booher, 2010). Instead of attending another community meeting people would rather spend their 'leisure-time' on activities they appreciate and truly enjoy (Lerner, 2014). Other authors emphasise that citizens still engage but the ways of communication have 
changed drastically, complementing and partly even replacing community meetings and co-located participatory action with digital tools and social media (Ekman \& Amnå, 2012; Gordon \& Mihailidis, 2016; Hay, 2007; Kleinhans, van Ham, \& Evans-Cowley, 2015; Macafee \& De Simone, 2012; Marichal, 2013; Skocpol, 1997; Tufekci \& Wilson, 2012). In different planning and design-related disciplines, digital tools for online participation, such as e-democracy portals, online consultations, e-voting, crowdsourcing, blogging, social network platforms, mobile apps, community GIS, and online deliberation, have gained increased attention as instruments to involve citizens and actor groups who either are too busy or not interested to participate in co-located meetings (e.g., Ahmed, Mehdi, Moreton, \& Elmaghraby, 2015; Belluci et al., 2015; Kelley \& Johnston, 2011; Prandi, Roccetti, Salomoni, Nisi, \& Jardim Nunes, 2017).

Such tools have raised expectations of the potential to overcome barriers to public participation such as the lack of long-term engagement, inclusion, and empowerment of underrepresented actor groups, as well as more broadly to make the process of public participation more pleasant and enjoyable. The vivid academic debate on the development and benefits of novel formats and tools, especially on games and gamified environments and tools (e.g., Devisch, Poplin, \& Sofronie, 2016; Medema, Furber, Adamowski, Zhou, \& Mayer, 2016; Poplin, 2014; Tolmie, Chamberlain, \& Benford, 2014), strongly focuses on the 'supply side' of the issue. The term 'supply' addresses the conceptual framing, design and development, and experimental testing of serious games and tools in public participation and urban governance, typically within the context of a research project or a living lab. Less attention is paid to the 'demand side': the investigation of the actual practises, experiences, expectations, and barriers to implementing and facilitating such tools in the daily, regular work practice. In this article we target this gap, by investigating the experiences of planning professionals with novel formats, namely games and gamified applications in their daily practice, addressing the following research questions: (i) which formats actually form part of the daily practice in participatory urban planning processes?; (ii) which benefits and advantages do facilitators identify in working with such formats?; and (iii) what are barriers which impede the willingness and ability to work with and facilitate such formats?

The article is organised as follows: in Section 2 we introduce the academic debate around games and gamified applications in addressing long-standing challenges relating to civic participation in urban planning and outline how games and gamified applications have been used in urban planning and governance so far. Section 3 describes the methodological approach and the three case study cities. In Section 4 we present and discuss our findings regarding the current state of participation in the three case study cities as well as the perceived benefits and obstacles in employing games and gamified applications within participatory planning settings.
Finally, in Section 5 we return to our research objectives to conclude that games and gamified applications could claim a larger share of the tools employed within participatory planning processes, when their development process is based on co-creation with the participating publics, when they are simple and developed with careful use of the available resources, and when process facilitators are better educated and better able to judge the situations in which such tools could be implemented as part of the planning process.

\section{Serious Games and Gamified Applications in Participatory Planning Practice}

Civic engagement and citizen participation can be broadly defined as the sum of political and social practices, by which individuals engage with and influence public affairs, beyond their direct private environment (Gordon, Balwin-Philippi, \& Balestra, 2013; Parés \& March, 2013; Raphael, Bachen, Lynn, Balwin-Philippi, \& McKee, 2010). Engagement and participation has become an inherent part of urban planning and governance, and is facilitated by different tools and methods, well beyond its traditional expressions of voting and attending town hall meetings (Gordon \& Mihailidis, 2016). Participatory methods are used to address a variety of aspects in urban planning and architectural design, including design issues, stakeholder negotiations and deliberation, and enabling self-organisation (Glick, 2012; Grahan \& Marvin, 2001; Krasny, 2013; Uitermark \& Duyvendak, 2008). Experimenting with novel tools and technologies, such as mobile apps, social media, games and gamified environments are efforts to both, diversify the media used for civic engagement, support the creation of different results, and at least partially address persistent common underlying problems (Rowe \& Frewer, 2000; Shipley \& Utz, 2012), such as the oftendownplayed undercurrent of social conflict and power struggles (Fainstein, 2000; Sandercock, 1994), the inequality of bargaining power among various stakeholders (Lane, 2005) or deal-brokering behind closed doors (Innes \& Booher, 2004), the overrepresentation of the so-called usual suspects and extreme viewpoints (Fiorina, 1999); the difficulties of including socioeconomically disadvantaged groups, the lack of expertise and motivation among citizens, high drop-out rates, as well as the lack of trust in the government's ability to make good use of the participatory processes (Brown \& Chin, 2013; Irvin \& Stansbury, 2004; Tonkens, 2014). A broad range of digital media and tools enter the field of civic participation because of their ability to incorporate larger volumes of data and information of different types (visual, textual, sound, etc.) and to present them in user-friendly formats to raise awareness and engage a broader audience (Gramberger, 2001; Kleinhans et al., 2015). Providing information and participation opportunities for distributed and remote citizens has also entered governmental offices and public bodies, often resulting in the 
establishment of 'innovation offices' responsible for an increasing number of digital online services and newly developed or redesigned, more easily accessible engagement tools (Conroy \& Evans-Cowley, 2005; Gordon \& Mihailidis, 2016). Even though the 'supply' of new formats demonstrates an extensive variety of new tools, the experimentation with and adoption of novel participatory formats by the 'demand side' is not straightforward. Many planners address the lack of sufficient education and training in participatory methods (Ekman \& Amnå, 2012; Handley \& Howell-Moroney, 2010; Innes \& Booher, 2004). Others report on the limitations posed by existing regulatory frameworks which enforce the use of specific methods and fail to follow the pace of technological development of innovative engagement tools (Houghton, Miller, \& Foth, 2014). Within public administration, lack of time, knowledge, and desire are also debated as being important reasons for non-participation (Yang \& Callahan, 2007).

In urban planning, the use of games in particular has a profound history since the 1960s (Abt, 1969; Duke, 1975), and has remained a popular tool for spatial modelling and simulation, and public participation (Devisch et al., 2016; Mayer, 2009; Poplin, 2012). Even though a universally shared definition of what constitutes a 'game' is lacking, there is agreement that games are a form of structured play (Salen \& Zimmerman, 2004). That means that games include sets of rules that enable and restrain the players' pursuit of a predetermined goal. 'Serious games' is a more recent field of game studies focusing on games that also include educational goals, instead of exclusively being for amusement (Abt, 1969). Early applications of serious games in urban planning focused mainly on ways to overcome challenges on the level of understanding and modelling urban dynamics, addressing topics such as land use, transportation, ecology, and management of natural resources. One of Abt's first urban games was 'Corridor' (Abt, 1969), a computer-assisted simulation game, to explore the technological, economic and political constraints on the development of an alternative transportation plan for the Northeast Corridor, between Boston and Washington D.C. In the 1960's and 70's Jay Forrester's (1969) work on urban dynamics inspired a series of urban simulation games, such as the games developed by Meadows and Randers for the Club of Rome, and even the popular city-building game SimCity (Mayer, 2009). 'Climate Hope City' (Blockworks, 2015) and 'Port of the Future' (Deltares, 2016) are contemporary simulation games, addressing challenges of resource management, urban power grid simulations, renewable energy and decision making. Even though simulation and modelling still play a pivotal role in urban planning and policy games, the potential of games to create environments for learning, negotiation, deliberation and collaboration among players is attracting increasingly more attention, which is also informed by the rising interest in gamification (Devisch et al., 2016; Gordon \& Baldwin-Philippi, 2014; Poplin, 2012; Tan, 2014). Many recent games provide ample opportunities for analogue and digital social interaction among players. The DuBes Game (van Bueren, Mayer, Bots, \& Seijdel, 2007), for example, is explicitly organised around two workshop sessions where players assume different stakeholder roles and negotiate an agenda for sustainable urban renewal. 'Age of Energy' (Clicks and Links, 2015) in an app-based game where players compete against their neighbours to save energy in real life. In such games, we ascertain a shift of focus from spatial understanding towards social aspects of playing in hybrid game-real-world settings.

Deterding et al. (2011) stress the importance of a strict distinction between gamification, and (serious) games. While games are considered to trigger the experiential and behavioural qualities of gameplay, gamified applications are notably centred around the use of specific game elements invoking gameful (ludic) qualities (Deterding, Dixon, Khaled, \& Nacke, 2011). Gamification describes "the use of game design elements in non-game contexts" (Deterding, Dixon, Khaled, \& Nacke, 2011). Gamification came to prominence in the early 2010's, mainly as enhanced advertising and marketing practices, where game elements such as points, badges and leaderboards were used to motivate audiences to engage with certain applications or brands (Huotari \& Hamari, 2011; Lindqvist, Cranshaw, Wiese, Hong, \& Zimmerman, 2011; Zichermann \& Cunningham, 2011). Gamification has been contested by several researchers especially within game studies, as reducing games to simple point collection (Robertson, 2010), as a form of exploitation (Bogost, 2011, 2014), and as a face-saving mechanism preventing deeper engagement (DiSalvo \& Morrison, 2011). Gamification is often applied in participatory urban planning by using game elements to enable citizens to debate or give feedback on specific plans and to propose ideas for small-scale projects. For example, in Participatory Chinatown (Gordon, 2010), citizens were able to virtually walk around Boston's Chinatown and comment on the proposed developments. In 'Neighborland' (Parham, Parham, \& Chang, 2011) civic organizations can inform and engage citizens about their projects, run surveys, and ask people to comment and propose ideas.

The interest of urban scholars in serious games and gamified applications stems from games' specific ability to balance entertainment and learning (Abdul Jabbar \& Felicia, 2015; Boyle, Connolly, Hainey, \& Boyle, 2012; Whitton, 2011). The learning aspects of gaming have more recently been associated with a series of benefits for participation and civic engagement, such as raising awareness, increasing literacy on specific topics, developing (complex) problem solving skills, the ability to test difficult scenarios within a safe environment, and to establish networks and coalitions (e.g., Crookall, 2010; Erhel \& Jamet, 2013; Gee, 2005; Granic, Lobel, \& Engels, 2014; Luederitz et al., 2016; Shaffer, Squire, Halverson, \& Gee, 2005). In this article, we investigate how experimentation with games and gamified applications takes 
place in participatory urban planning practice, the benefits as seen by planners and facilitators, as well as barriers which they are confronted with in their daily work.

\section{Methodological Approach and Introduction to the Case Studies}

The experiences and expectations of urban planners in using serious games and gamified applications to support participatory urban planning practices were studied in the cities of Groningen (NL), Vienna (AT) and Genk $(B E)$. The case study selection is based on the research project that this work is embedded in. The three cities cover a broad spectrum of spatial and socio-cultural settings. Even though we expected to see diverse applications of participatory processes due to the different institutional, spatial, socio-economic and cultural conditions, and the broad variety of experiences and expectations resulting from the broad cultural and institutional contexts, we were able to combine the observations from the three cities due to the commonalities observed re- garding the organisation and facilitation of participatory processes as well as the tools that were used during such processes (Table 1).

The article is based on an explorative case study research (Scholz \& Tietje, 2002; Yin, 2013) following a two stages approach, combining an initial online explorative survey with guideline-based expert interviews. The survey was used to collect background information, to systematically map the participatory approaches, tools and methods currently in use within planning processes, as well as to identify which topics were addressed, which audiences were included, and the perceived impact of participation on the planning processes. The survey also covered the participants' general experience with games and gamified applications in the three cities and delivered the basis for the interview guidelines. Interviews were carried out in English, in Groningen and Genk, and in German in Vienna and all were based on the same guidelines. The expert interviews (Groningen: 8, Vienna: 7, Genk: 9), covered professionals within the fields of public administration (10 interviews), research

Table 1. Overview of the three case studies and the participatory methods used in Vienna, Genk and Groningen, based on the expert interviews and document analysis.

\begin{tabular}{|c|c|c|c|}
\hline City & Vienna (AT) & Genk (BE) & Groningen (NL) \\
\hline $\begin{array}{l}\text { Current focus regarding } \\
\text { planning \& development }\end{array}$ & \multicolumn{3}{|c|}{$\begin{array}{l}\text { Urban planning, community development, mobility, energy transition, carbon } \\
\text { footprint, local economy }\end{array}$} \\
\hline $\begin{array}{l}\text { Process planning \& } \\
\text { design }\end{array}$ & $\begin{array}{l}\text { District service, area } \\
\text { renewal office, agenda } 21 \\
\text { office }\end{array}$ & $\begin{array}{l}\text { Neighbourhood } \\
\text { management (Wijk } \\
\text { management) }\end{array}$ & $\begin{array}{l}\text { Process management, } \\
\text { public servants }\end{array}$ \\
\hline \multirow[t]{2}{*}{$\begin{array}{l}\text { Implementation: } \\
\text { methods facilitated }\end{array}$} & \multicolumn{3}{|c|}{$\begin{array}{l}\text { Large variety: focus on traditional, well-established methods, like focus groups or } \\
\text { brainstorming techniques, partly extended by social media platforms }\end{array}$} \\
\hline & $\begin{array}{l}\text { Workshops, brainstorming } \\
\text { techniques, focus groups, } \\
\text { public interventions }\end{array}$ & $\begin{array}{l}\text { Brainstorming } \\
\text { techniques, } \\
\text { meetings/discussion } \\
\text { rounds }\end{array}$ & $\begin{array}{l}\text { Meetings, discussion } \\
\text { rounds, information } \\
\text { distribution }\end{array}$ \\
\hline $\begin{array}{l}\text { Resource restrictions on } \\
\text { participant level }\end{array}$ & $\begin{array}{l}\text { Time, knowledge, language } \\
\text { barriers, educationally } \\
\text { deprived groups \& low- } \\
\text { income groups, cultural } \\
\text { restrictions (hard-to-reach- } \\
\text { groups) }\end{array}$ & $\begin{array}{l}\text { Time, knowledge, } \\
\text { language barriers, } \\
\text { cultural restrictions }\end{array}$ & $\begin{array}{l}\text { Knowledge, know } \\
\text { how/technical capacity, } \\
\text { language barriers } \\
\text { (present but not } \\
\text { perceived) }\end{array}$ \\
\hline Diversity & \multicolumn{3}{|c|}{$\begin{array}{l}\text { Underrepresentation of non-European groups, adults/working population (well } \\
\text { represented) and elderly people (65+) tendency towards over-representation }\end{array}$} \\
\hline Digital tools & $\begin{array}{l}\text { Participatory GIS, mobile } \\
\text { apps, quizzes, online forums } \\
\text { and feedback forms, tv, } \\
\text { radio, project website }\end{array}$ & $\begin{array}{l}\text { Photography, filming, } \\
\text { quizzes, online forums, } \\
\text { tv, radio, project website }\end{array}$ & $\begin{array}{l}\text { Surveys (online), social } \\
\text { media monitoring, } \\
\text { photography, filming, } \\
\text { online reaction forms, tv, } \\
\text { radio, project website }\end{array}$ \\
\hline $\begin{array}{l}\text { Games and gamified } \\
\text { applications }\end{array}$ & $\begin{array}{l}\text { Board games, explorative } \\
\text { board games for idea } \\
\text { development, role playing, } \\
\text { street games }\end{array}$ & $\begin{array}{l}\text { Educational games, } \\
\text { games in a business } \\
\text { context, urban games, } \\
\text { story-collecting birds }\end{array}$ & $\begin{array}{l}\text { Gamified participatory } \\
\text { GIS, city development } \\
\text { game }\end{array}$ \\
\hline
\end{tabular}


( 3 interviews) and facilitators of public participation processes, such as civic engagement offices or district renewal agencies (11 interviews). The expert interviews made an in depth exploration of the variety of participatory projects and engagement processes that the interviewees employed in their daily practices, the perceived value of using participatory processes, the diversity of methods and (digital) tools that were used, as well as the problems they encountered. Based on their previously declared familiarity with games and gamified applications, the interviews explored either their experiences of employing such tools and their (positive or negative) evaluation of the reasons for not engaging with alternative formats, as well as their expectations. The interviews were transcribed, coded and analysed using qualitative content analysis (Gläser \& Laudel, 2010; Mayring, 2015).

Participatory processes and tools have been analysed using Horelli's (2002) methodological scheme of participatory planning, conceptualizing it as an evolutionary process that unfolds over time and consists of five generic steps, in which multiple tools can be used to facilitate communicative transactions among participants in specific environmental, organizational, economic, cultural and temporal contexts: (i) initiation of the project, (ii) planning and design, (iii) implementation, (iv) evaluation and research, and (v) maintenance (Horelli, 2002). These phases are interconnected by a continuous monitoring, providing feedback on the progress, quality and results of the process. Facilitating tools are structured in four categories based on their potential to enable communicative transactions: (i) diagnostic tools enable the determination of existing resources, mapping of the context and definition of the desired outcomes of the process; (ii) expressive tools enable participants to communicate their ideas and express themselves; (iii) organizational tools are those that underlie the organization of the process, including the creation of events, and (iv) political tools address common goal setting and power differences (Horelli, 2002).

\section{Current State of Use of Games and Gamified Applications in Participatory Settings in Vienna, Groningen and Genk}

The identified commonalities among the three case study cities notably surpass their differences in the scope of tools used in participatory settings (Tables 1 and 2). These commonalities allow the establishment of the 'demand side' regarding employment of games and gamified applications. Most participatory projects mentioned by the interviewees were linked to urban planning, infrastructure development, community development and the local economy, and were initiated and commissioned by a governmental organisation. The projects also varied in scale, ranging from street level to neighbourhood and city-wide, as well as infrastructure, urban policy, and urban design. For the most part, these are projects that are considered to be highly relevant to citizens' daily life, such as community building processes, projects directly linked to the (spatial) quality of the neighbourhood and quality of life, and big infrastructure projects that are expected to affect a large population over an extended period of time. Municipalities, groups of organisations and activist initiatives play an important role in launching topics, raising awareness, and initializing participatory projects. However, civic participation is often outsourced to intermediary organisations and planning agencies. Thus, the demand for new ways of engagement stems not only from the decision-making bodies, but also from these intermediaries and other initiating stakeholders.

A broad variety of tools and methods are already in use across all four categories of Horelli's (2002) framework (Table 2). A great deal of emphasis is placed on the initiation, and the planning and design phase, where the large majority of tools are concentrated. These are the most intensive phases of the participation process because they will enable the project to proceed smoothly. Comparatively little attention is paid to the evaluation phase, with a few instances of feedback being sought following the success of the projects, with fewer tools being used during the implementation and maintenance phases. These phases are often considered 'technical', in the sense of their being able to be carried out in a straightforward way by expert professionals, and thus are thought to not require broader public engagement. A large number of tools are classified as organizational: these are mostly tools that provide project information, information about the development process, and the state of works to the public. Exhibitions, guided tours, and leaflets tools are the only tools which have a significant presence during the implementation phase, these being tools which provide information but collect no feedback. The political category has the least number of tools available to it; there being very few tools used that address common goals and power differences of participating actors which points to the lesser importance given to questioning the predefined conceptual structures of the planning processes. Finally, regarding the nature of the tools, even though digital tools are consistently present throughout the process and across all categories, non-digital tools continue to dominate the daily participatory planning practice.

The facilitators and planners generally choose the tools and methods they feel the most comfortable with, resulting in the prevalence of non-digital methods and tools: "real games in the narrower sense are not used. Well, we have-we use more traditional methods, such as moderations and surveys and such" (VIE-JG). Even though the more 'traditional' formats implied in this quote remain the majority, experimentation with new media and digital tools also exists. The use of these tools happens either very early in the process with the aim to initiate and support an active and positive start of the participatory process (e.g., activation of participants, getting acquainted, capacity building on the planning pro- 
Table 2. Overview of tools used in participatory processes in the three case study cities, following Horelli (2002).

\begin{tabular}{|c|c|c|c|c|c|c|}
\hline & & PLANNING PRC & CESS & & & \\
\hline & & Initiation & $\begin{array}{l}\text { Planning \& } \\
\text { Design }\end{array}$ & Implementation & $\begin{array}{l}\text { Evaluation \& } \\
\text { Research }\end{array}$ & Maintenance \\
\hline Diagnostic & Non-digital & $\begin{array}{l}\text { Surveys } \\
\text { (offline), } \\
\text { interviews }\end{array}$ & & & $\begin{array}{l}\text { Surveys } \\
\text { (offline) }\end{array}$ & \\
\hline & Digital & $\begin{array}{l}\text { Surveys } \\
\text { (online), } \\
\text { social media } \\
\text { monitoring, } \\
\text { photography, } \\
\text { filming, } \\
\text { participatory } \\
\text { GIS }\end{array}$ & & & $\begin{array}{l}\text { Surveys } \\
\text { (online), } \\
\text { social } \\
\text { media } \\
\text { monitoring }\end{array}$ & \\
\hline Expressive & Non-digital & $\begin{array}{l}\text { Interviews, } \\
\text { focus groups, } \\
\text { consultation } \\
\text { meetings, } \\
\text { workshops, } \\
\text { activation } \\
\text { games, } \\
\text { quizzes }\end{array}$ & $\begin{array}{l}\text { Architectural } \\
\text { models, } \\
\text { interviews, } \\
\text { focus groups, } \\
\text { consultation } \\
\text { meetings, } \\
\text { games, } \\
\text { workshops, } \\
\text { brainstorming }\end{array}$ & & Interviews & \\
\hline & Digital & $\begin{array}{l}\text { Mobile apps, } \\
\text { games, } \\
\text { quizzes }\end{array}$ & $\begin{array}{l}\text { Mobile apps, } \\
\text { online forums } \\
\text { and feedback } \\
\text { forms, games }\end{array}$ & & $\begin{array}{l}\text { Mobile apps, } \\
\text { online } \\
\text { forums and } \\
\text { reaction } \\
\text { forms }\end{array}$ & $\begin{array}{l}\text { Online } \\
\text { forums and } \\
\text { feedback } \\
\text { forms }\end{array}$ \\
\hline Organizational & Non-digital & $\begin{array}{l}\text { Local press, } \\
\text { policy } \\
\text { documents } \\
\text { and reports, } \\
\text { brochures and } \\
\text { flyers, press } \\
\text { conferences, } \\
\text { letters }\end{array}$ & $\begin{array}{l}\text { Guided tours, } \\
\text { exhibitions, } \\
\text { info points, } \\
\text { on-site info } \\
\text { panels, } \\
\text { brochures } \\
\text { and flyers, } \\
\text { letters }\end{array}$ & $\begin{array}{l}\text { Guided tours, } \\
\text { exhibitions, info } \\
\text { points, on-site } \\
\text { info panels, } \\
\text { brochures and } \\
\text { flyers }\end{array}$ & $\begin{array}{l}\text { Policy } \\
\text { documents } \\
\text { and } \\
\text { reports, } \\
\text { letters }\end{array}$ & \\
\hline & Digital & $\begin{array}{l}\text { Tv, radio, } \\
\text { project } \\
\text { website, }\end{array}$ & $\begin{array}{l}\text { Project } \\
\text { website }\end{array}$ & $\begin{array}{l}\text { Project } \\
\text { website }\end{array}$ & $\begin{array}{l}\text { Project } \\
\text { website }\end{array}$ & $\begin{array}{l}\text { Project } \\
\text { website }\end{array}$ \\
\hline Political & Non-digital & Fund-raising & $\begin{array}{l}\text { Participatory } \\
\text { budgeting }\end{array}$ & Co-financing & $\begin{array}{l}\text { Citizen } \\
\text { panels }\end{array}$ & \\
\hline
\end{tabular}

cesses), or later in the process to produce content in the planning and design phase (e.g., developing a proposal for a park, strategy development for a harbour). As for the production of content, the focus is on using a variety of expressive tools for the development of planning proposals (e.g., neighbourhood parks and squares in Vienna), urban strategic plans (e.g., port redevelopment in Rotterdam), and for considering perspectives and wishes from various stakeholders and actors:
We used it in a part of the former harbour, not so much for urban planning, more to get an urban strategy and to make a deal with all participants because there were private owners, the central Dutch government, the city, all kinds of parties who had some role in this whole area. (GRO-ES)

With regards to the process, we see that especially in early stages of participatory processes gamified applica- 
tions are facilitated, targeting activation, allowing participants to become acquainted with one another, or developing the knowledge required to enter the participation process: "Rather 'activation-games' and also quizzes for knowledge creation about the carbon footprint or mobility" (VIE-SH). New media and digital tools are used regularly to motivate and inform participants, but also at later stages they can lower threshold for participation, acting as icebreakers and facilitating social interaction within the group of participants: "it's an extra way for people to get in, I think.....It's a way of connecting with others" (GRO-AH) or "But you can see all kinds of groups processes going on....It's not only about the plan or the development but also about the interaction in the group" (GRO-ES).

\subsection{Experienced Benefits of Games and Gamified Applications in Participatory Processes}

We illustrated that so-called 'traditional' methods for civic engagement in participatory urban planning coexist with experimentation using novel media, tools, and games. Three main perspectives emerged from the case studies showing the perceived benefits of using games and gamified applications for participatory processes: (i) to illustrate complex urban issues and make the complexity more tangible, (ii) to evoke social learning and capacity building, and (iii) to make the participatory processes 'lighter' and easier to attend.

As to our first point regarding the illustration of complex urban issues, serious games are experienced as suitable formats to illustrate the complexity of urban matters and to make them more tangible. The real-world complexities are then mirrored in the artificial game context. Hence, relations or outcomes of decision-making processes that in the 'real-world' are difficult to experience become visible in the game. Topics such as energy transition, urban planning and urban matters include multiple tiers of policy, a broad variety of actors, conflicting policies, and they touch on politically and societally charged topics: "Perhaps one can say, the more complex the issue is, the more likely the game can achieve something" (VIE$\mathrm{MF}$ ) or "Everything can be more accessible via the use of games, certainly mostly the politically and societally loaded topics." (GEN-LA).

Instigating learning and capacity building (Gugerell, Jauschneg, Platzer, \& Berger, 2017), communicating and understanding conflicting interests of various stakeholders and actor groups are considered pivotal, and games are seen as being significant tools:

It was about complexity [of the project, $\mathrm{A} / \mathrm{N}$ ] and to make people, participants realise what the interests of the other participants were and to get to the bottom of these interests....You give people different roles they don't have in real life. (GRO-ES)
The quote sheds light on the importance of games as communication and negotiation environments, where different perspectives and viewpoints can be shared, discussed, deconstructed, and negotiated by the players. Within the game setting "you get people in a situation that they are willing to look differently to this map and so they get away a little bit from their sometimes very small private interests" (GRO-ES) and:

Trying to explore and to immerse oneself into a topicand you explore and experience many things, that one should consider. But you also get to know the 'other side', it's-yeah-also a communicative process. (VIE-MF)

It illustrates that games as artificial contexts allow actors to step out of their everyday realities and explore alternative perspectives and possible practices. Hence the second reported benefit is that playing games not only supports visualizing complex planning issues but also instigates processes of social learning and civic capacity building. In the interviews, capacity building was framed as obtaining skills and knowledge of the planning processes and related administrative procedures of the public administration and planning departments: "So people can learn how to get involved in the process and also in projects" (GRO-JKK). But games are particularly valued for triggering, facilitating, and consolidating learning processes:

Games were used as a consolidation of other learning processes: in a heuristic way, heuristic meaning as a structuring aid for the discovery of certain types of knowledge, or discovery of their own strengths and weaknesses in a particular set. (GEN-VVdS)

The material suggests a strong interest in game components and approaches that support negotiation and deliberation, with a particular focus on collaborative settings:

You have to collaboratively reach the goal [in the game, $\mathrm{A} / \mathrm{N}$ ]. Thus, the game is very similar to a participatory process....That there is a winner in the game? No, I believe that's not favourable-because it contradicts the participatory idea: I do not want a winner. I do not want that the strongest, quickest or smartest will dominate and prevail. (VIE-MF)

Those multiplayer, collaborative games involve a strong social component, contrary to playing alone or against a computer. Multiplayer games are based on interaction with other people (e.g., debating about different interests, exploring a strategy, praising the achievement of other players), but for games to be appealing and fun, they also need competitive elements that make playing with (not necessarily against) other players challenging (see also Wendel \& Konert, 2016): 
Everyone can allocate a point to his favourite measure-and in the end there is somebody winningtherefore it also has a competitive element....That means that all of them endeavour, because sometimes the topics are also a bit 'dry'. (VIE-JG)

Hence, instigating and supporting different types of collaboration, such as building shared knowledge, resolving conflicts and different interests, motivation and joint goal achievement (Guzzetti, Snyder, Glass, \& Gamas, 1993) appear as a major requirement throughout our research. A balance between collaboration and competition appears to be a preferable game setting for media and tools that are used in such participatory approaches.

Finally, the reference towards 'dry' topics points towards another important benefit addressed in the interviews: games and gamified applications are expected to make participatory processes lighter and more enjoyable: "The advantage of using games is the low threshold, low design, people buy easily into it, they go along with them. Creates a relaxed, fun atmosphere, that is something that is appreciated by the people." (GEN-PV). By doing so, they are expected to improve the overall quality of the participatory process by 'playful deliberation' (VIE-JG), 'playful engagement' (VIE-FM) and by increasing the 'fun-factor': "I believe, the fun-factor is crucial, when you think through and work with games. Very often the games are so serious-too serious, that I even think by myself 'there are fun elements missing'"' (VIE-MF) and "because it's something playful, something where the people get a kick out of it" (VIE-SH). Thus, we see the practical importance of balancing serious games with an equilibrium of serious content and game-fun (Harteveld, 2011; Iten \& Petko, 2016; Malone \& Lepper, 1987) that results in a joyful game and learning experience (Gugerell et al., 2017). However, it is crucial to stress that though serious games primarily serve 'non-entertainment' purposes, they still need to be fun and entertaining to a certain degree to meet both the needs of planning practice and the participants' expectations.

\subsection{Perceived Barriers to the Use of Games and Gamified Applications in Participatory Settings}

Both urban planners and process facilitators shared an enthusiasm towards the use of games and gamified applications, with external process facilitators being slightly more open in adopting these new formats than the planners. However, despite the generally positive attitude towards games and gamified applications in participatory urban planning approaches, in all case study cities, similar barriers and challenges seem to impede their regular use. In our research, three main barriers are identified: (i) the modest gaming experience of the facilitators and the planning departments, (ii) a resource scarcity that limits the development of and engagement with such tools, and finally (iii) the fear of reluctant adults to make a fool of themselves.
In all case study cities, the professional experience with games or even gamified environments is modest to limited, with only about a third of the interviewees having previously used games or gamified applications in participatory processes. This limited practical experience reduces the understanding of the potential value of such games in participatory processes. This perception is not only limited to planners and facilitators but is present in senior and high ranking representatives of the public administration:

Personally, I am not from the gaming generation. So, gaming is kind of alien to me....And unfortunately, most of my colleagues are of my age. I'm almost 50 and I am on the average of the municipality, so we have a very old population. As a consequence, there is not a lot of knowledge about gaming, I would actually say there is not enough knowledge. And I think that most people in our government see gaming, you know, as video gaming, doing stuff, shooting people...crashing cars, stuff like that...but gaming as part of a participation process: I don't think that many people have ever thought about that. (GRO-JKK)

The modest experience with games also makes it hard to assess and estimate resources needed and expenditure for the development and facilitation of games. "The drive to be efficient and not having a lot of money to get things done, I think prohibits us from taking this step to experiment with [games, N/A]" (GRO-ES). This quote illustrates a possible tension between resource availability, applicability, and repeatability of developed games or game components and the expected benefits on the participatory process itself. Time and budget constraints, paired with the expectation that games require a more elaborate development process, compared to 'traditional' methods, are decisive impediments to the development and facilitation of games in planning practice: "it takes a lot of time and thinking to develop a game" (GROES) and "Digital games are really time-consuming to produce" (GEN-LB). This constraint is reinforced by the argument that games are mostly tailored to specific spatial contexts or regulatory frameworks and thus cannot be adapted to other topics or conditions: "Regarding games we are not active at all, because it's too cumbersomeand for each case it would be necessary to develop something separately or be able to convert it" (VIE-MF) or "Yes, for the game development, you must invest something and then I need the option to use it more often-and it only pays off, if I-ok for every Agenda [Agenda21, A/N] action on the topic I can use it at least ten times" (VIE$\mathrm{SH})$. There is also a certain 'mystification' of the game design process; because of their lack of training and confidence, planners question whether games can actually be suitably designed to achieve their goals: "You can design games in so many different ways to so many different objectives, to include and diffuse so many different kinds of knowledge....It is so flexible in format and this 
represents as well a challenge because to design in that space something that really works, it is not given" (GEN$\mathrm{PV}$ ) and "There is no proof that serious games can produce behaviour changes." (GEN-LB).

Finally, another central concern regarding the broader implementation of games and gamified applications were difficulties with the adult participant group, which makes up the majority of those in the participatory processes that were examined. While games are thought of as being suitable tools to attract participants and to "get people enthusiastic" (GRO-AH) serious concerns are also being voiced regarding their broader use. While games and gamified applications are known to work well in collaborative practices with children, teenagers and young adults, serious concerns regarding their applicability with adults were addressed: "My experience is, that it's [playing games, N/A] fantastic for kids; adults dare only rarely to engage-ok, it depends on the setting. Frankly, I have hesitations, how far you are offering that, or not" (VIE-SH) and "The risks in using games are that people see it as childish, there is always a balance you should make in addressing something playfully, without leaving the impression that what you are doing is mere entertainment." (GEN-LA). Those concerns were shared by about a fifth of the interviewees, who expressed their difficult experiences with sceptical and reluctant adults. Facilitators are concerned that participants would either torpedo, leave or discredit the entire process by questioning its seriousness:

They [participants, N/A] then often said 'that's utter nonsense' and 'what the heck are you doing here'....and with the adults, once one person left. She said, 'that's childish and immature and I don't participate in such a thing'. That happened on the first evening-and she did not come back afterwards" (VIE-MR)

On the other hand, the research also indicates that if this initial reluctance can be broken, adults will also engage in game activities:

I think most people were beforehand quite reluctant because they didn't come for a game, but they came for a serious discussion.....But what you see is that more participants, in the end, say 'oh! now I understand why he or she is doing that'....Like I said, most people are reluctant because they say 'I am not here to play a game. I am here for serious business' (GRO-ES)

and "When playing the game, at the beginning, participants are always a bit reluctant, they are a bit afraid of using colours, images, saying their opinion etc." (GEN-LH). Other facilitators are more willing to abandon the tool because they are too concerned: "Well, M. and H. were very consequent in that regard, they continued with the group-games, but-well, I would not have continued to play them, I would have given up." (VIE-MR). The material illustrates that adults are considered a difficult age group to engage with via games and gamified activities in participatory processes, due to their expectation that they should be participating in and negotiating in 'serious business'. The issue of this being an unusual format and medium that is regularly associated with entertainment and children, does not align with the fact that the average (video) gamer is 35 years old for men and 44 for women (Entertainment Software Association, 2016). However, it clearly indicates that the concern of the facilitators and the reluctance of this age group must be sufficiently considered in both the game design and the participatory process.

\section{Conclusions}

Even though games and gamified applications are not the panacea to the longstanding issues of civic participation, they do open up new possibilities for engagement and contribute to the diversification of methods and tools available to the facilitators of these processes. Despite the vivid academic debate on serious games and gamification in various planning contexts (Abt, 1969; Devisch et al., 2016; Gordon \& Baldwin-Philippi, 2014; Mayer, 2009; Poplin, 2012; Tan, 2014), our research indicates a notable gap between research and practice. The analysis shows that experimentation with games and gamified applications indeed takes place in planning practice and urban governance, but to a much lesser extent than was initially expected, and it should be noted that there are serious concerns regarding their overall applicability.

Facilitators and planners acknowledge the value and benefits of games, to aid the understanding of complex matters, trigger focus group discussion, and to illustrate and support decision-making processes. Hence our research aligns with scholars such as Gee (2005) and Crookall (2010) who illustrate the value of games for learning and capacity building processes. However, modest experience and knowledge, limited resources, and a lack of adaptability of games for differing occasions, cases, and audiences pose impediments to the broader facilitation and use of games in participatory processes. The insufficient education and lack of training of process facilitators cover a variety of participatory methods (Innes \& Booher, 2004). With specific regard to games and gamified applications, facilitators' lack of experience results in an inability to clearly estimate their potential and the ways they can assist the participatory practice. The research illustrates that planners and policy-makers do not make a clear distinction between games and gamified applications and use these terms interchangeably, which leads to a certain fuzziness in the practices they adopt and which often results in either disappointment following their application, or to the exclusion of such tools from the participatory process altogether. Consequently, the conscious identification and selection of digital tools and formats for participatory processes is com- 
promised by this fuzziness, adding another layer of conditioning of the participatory practices by the preconceptions and modestly-informed decisions of facilitators. Hence, capacity building of facilitators regarding the new formats which are available can support the emergence of a culture of experimentation with a range of tools and digital media, including games.

To counter the mentioned lack of financial resources and time, the development of smaller game components and mini-games might be a suitable response towards an efficient use of games under such resource constraints. Mini-games can be advantageous for participatory practices because they are easier to balance between generic (to be adaptable to various occasions and projects) and specific (to the address the particular case and position in the process), combining in one tool the two separate attributes that Gordon et al. (2013) have identified. This quality makes it easier for mini-games to both meet the expectations and to fit in the rather tight budgets of planning practice. Finally, for the development and facilitation of games, adult users need particular attention paid to them: engaging adults in co-design and participatory game design processes might be beneficial to address this user group's reservations, while also contributing to the relevance and local embeddedness of the game or gamified application.

\section{Acknowledgements}

The article is a delivery of the research project "Playing with urban complexity. Using co-located serious games to reduce the urban carbon footprint among young adults", funded by JPI Urban Europe.

\section{Conflicts of Interest}

The authors declare no conflict of interests.

\section{References}

Abdul Jabbar, A., \& Felicia, P. (2015). Gameplay engagement and learning in game-based learning: A systematic review. Review of Educational Research, 85(4), 740-779.

Abt, C. (1969). Serious games. New York: Viking Press. Ahmed, A. M., Mehdi, Q. H., Moreton , R., \& Elmaghraby, A. (2015). Serious games providing opportunities to empower citizen engagement and participation in egovernment services. Proceedings of CGAMES 2015 USA: 20th International Conference on Computer Games: Al, Animation, Mobile, Interactive Multimedia, Educational and Serious Games (pp. 138-142). New Jersey: Piscataway.

Belluci, A., Jacucci, G., Kotkavuori, V., Serim, B., Ahmed, I., \& Ylirisku, S. (2015). Extreme co-design: Prototyping with and by the user for appropriation of webconnected tags. In P. Díaz, V. Pipek, C. Ardito, C. Jensen, I. Aedo, \& A. Boden (Eds.), End-user devel- opment. IS-EUD 2015. Lecture notes in computer science. 9083. Cham: Springer.

Blockworks. (2015). Climate hope city.

Bogost, I. (2011). Persuasive games. Gamasutra. Retrieved from www.gamasutra.com/view/feature/ 6366/persuasive_games_exploitationware.php

Bogost, I. (2014). Why gamification is bullshit. In S. P. Walz \& S. Deterding (Eds.), The gameful world: Approaches, issues, applications (pp. 65-80). Cambridge, MA: MIT Press.

Boyle, A., Connolly, M. T., Hainey, T., \& Boyle, M. J. (2012). Engagement in digital entertainment games: A systematic review. Computers in Human Behaviour, 28, 771-780.

Brown, G., \& Chin, S. Y. (2013). Assessing the effectiveness of public participation in neighbourhood planning. Planning Practice and Research, 28(5), 563-588.

Clicks and Links. (2015). Age of energy. Amsterdam Smart City, Cityzen.

Conroy, M. M., \& Evans-Cowley, J. (2005). Informing and interacting: The use of e-government for citizen participation in planning. Journal of E-Government, 1(3), 73-92.

Crookall, D. (2010). Serious games, debriefing, and simulation/gaming as a discipline. Simulation \& Gaming, 41(6), 898-920.

Deltares. (2016). Port of the future.

Deterding, S., Dixon, D., Khaled, R., \& Nacke, L. (2011). From game design elements to gamefulness: Defining "gamification". In MindTrek'11 (pp. 9-15). Tampere: ACM.

Devisch, O., Poplin, A., \& Sofronie, S. (2016). The gamification of civic participation: Two experiments in improving the skills of citizens to reflect collectively on spatial issues. Journal of Urban Technology, 23(2), 81-102.

DiSalvo, B., \& Morrison, B. (2011). Critique of "gamification" in Khan Academy. In DiGRA 2011.

Duke, R. (1975). Metropolis: The urban systems game. New York: Gamed Simulations, Inc.

Ekman, J., \& Amnå, E. (2012). Political participation and civic engagement: Towards a new typology. Human Affairs, 22(3), 283-300.

Entertainment Software Association. (2016). Essential facts about the computer and video game industry. Washington, DC: Entertainment Software Association.

Erhel, S., \& Jamet, É. (2013). Digital game-based learning: Impact of instructions and feedback on motivation and learning effectiveness. Computers and Education, 67, 156-167.

Fainstein, S. S. (2000). New directions in planning theory. Urban Affairs Review, 35(4), 451-478.

Fiorina, M. P. (1999). Extreme voices: A dark side of civic engagement. In civic engagement in American Democracy (pp. 395-425). Washington, DC: Brookings Institution. 
Forrester, J. (1969). Urban dynamics. Waltham, MA: Pegasus Communications.

Gee, J. (2005). Why are videogames good for learning? Spectrum, 32, 25-32.

Gläser, J., \& Laudel, G. (2010). Experteninterviews und qualitative Inhaltsanalyse. VS Verlag für Sozialwissenschaften.

Glick, D. (2012). Bottom-up urbanism: A survey of temporary use in Europe. Boston: Hart Howerton Community Fellowship. Retrieved from https://issuu. com/david.t.glick/docs/bottom-up_urbanism_dglick

Gordon, E. (2010). Participatory Chinatown. Engagement Lab, Emerson College.

Gordon, E., \& Baldwin-Philippi, J. (2014). Playful civic learning: Enabling reflection and lateral trust in gamebased public participation. International Journal of Communication, 8, 759-786.

Gordon, E., \& Mihailidis, P. (2016). Civic media: Technology, design, practice. Cambridge, MA: MIT Press.

Gordon, E., Balwin-Philippi, J., \& Balestra, M. (2013). Why we engage: How theories of human behavior contribute to our understanding of civic engagement in a digital era. Retrieved from http://cyber.law. harvard.edu/publications/2013/why_we_engage

Grahan, S., \& Marvin, S. (2001). Splintering urbanism: Networked infrastructures, technological mobilities and the urban condition. London: Routledge.

Gramberger, M. (2001). Citizens as partners: OECD handbook on information, consultation and public participation in policy-making. Paris: OECD.

Granic, I., Lobel, A., \& Engels, R. C. (2014). The benefits of playing video games. American Psychologist, 69(1), 66-78.

Gugerell, K., Jauschneg, M., Platzer, M., \& Berger, M. (2017). Playful participation with urban complexity: Evaluation of the co-located serious game mobility safari in Vienna. In REAL CORP 2017 (pp. 413-420). Vienna.

Guzzetti, B. J., Snyder, T. E., Glass, G. V., \& Gamas, W. S. (1993). Promoting conceptual change in science: A comparative meta-analysis of instructional interventions from reading education and science education. Reading Research Quarterly, 28(2), 116-159.

Handley, D. M., \& Howell-Moroney, M. (2010). Ordering stakeholder relationships and citizen participation: Evidence from the community development block grant program. Public Administration Review, 70(4), 601-609.

Harteveld, C. (2011). Triadic game design: Balancing reality, meaning and play. London: Springer.

Hay, C. (2007). Why we hate politics. Cambridge, MA: Polity Press.

Horelli, L. (2002). A methodology of participatory planning. In R. Bechtel \& A. Churchman (Eds.), Handbook of environmental psychology (pp. 607-628). New York: John Wiley.

Houghton, K., Miller, E., \& Foth, M. (2014). Integrating ICT into the planning process: Impacts, opportunities and challenges. Australian Planner, 51(1), 24-33.

Huotari, K., \& Hamari, J. (2011). "Gamification" from the perspective of service marketing. In CHI 2011. Vancouver: ACM.

Innes, J. E., \& Booher, D. E. (2010). Planning with complexity: An introduction to collaborative rationality for public policy. London and New York: Routledge.

Innes, J. E., \& Booher, D. E. (2004). Reframing public participation: Strategies for the 21st Century. Planning Theory and Practice, 5(4), 419-436.

Irvin, R., \& Stansbury, J. (2004). Citizen participation in decision making: Is it worth the effort? Public Administration Review, 64(1), 55-65.

Iten, N., \& Petko, D. (2016). Learning with serious games: Is fun playing the game a predictor of learning success? British Journal of Educational Technology, 47(1), 151-163.

Kelley, T., \& Johnston, E. (2011). Discovering the appropriate role of serious games in the design of open governance platforms. Public Administration Quarterly, 36(4), 1-24.

Kleinhans, R., van Ham, M., \& Evans-Cowley, J. (2015). Using social media and mobile technologies to foster engagement and self-organisation in participatory urban planning and neighbourhood governance. Planning Practice \& Research, 30(3), 237-247.

Krasny, E. (Ed.). (2013). Hands-on urbanism 1850-2012: The right to green. Hong Kong: MCCM creations.

Lane, M. B. (2005). Public participation in planning: An intellectual history. Australian Geographer, 36(3), 283-299.

Lerner, J. A. (2014). Making democracy fun: How game design can empower citizens and transform politics. Cambridge, MA: The MIT Press.

Lindqvist, J., Cranshaw, J., Wiese, J., Hong, J., \& Zimmerman, J. (2011). I'm the Mayor of my house: Examining why people use foursquare-A social-driven location sharing application. In CHI 2011: Proceedings of the SIGCHI Conference on Human Factors in Computing Systems (pp. 2409-2418). Vancouver: ACM.

Luederitz, C., Schäpke, N., Wiek, A., Lang, D. J., Bergmann, M., Bos, J. J., . . . Westley, F. R. (2016). Learning through evaluation-A tentative evaluative scheme for sustainability transition experiments. Journal of Cleaner Production, 169, 61-76.

Macafee, T., \& De Simone, J. (2012). Killing the Bill online? Pathways to young people's protest engagement via social media. Cyberpsychology, Behavior, and Social Networking, 15(11), 579-584.

Malone, T. W., \& Lepper, M. R. (1987). Making learning fun: A taxonomy of intrinsic motivations for learning. In R. E. Snow \& M. J. Farr (Eds.), Aptitude, learning, and instruction: Conative and affective process analyses (pp. 223-253). Hillsdale, NJ: Lawrence Erlbaum.

Marichal, J. (2013). Political Facebook groups: Microactivism and the digital front stage. First Monday, 18(12).

Mayer, I. S. (2009). The gaming of policy and the politics 
of gaming: A review. Simulation and Gaming, 40(6), 825-862.

Mayring, P. (2015). Qualitative Inhaltsanalyse: Grundlagen und Techniken. Beltz.

Medema, W., Furber, A., Adamowski, J., Zhou, Q., \& Mayer, I. (2016). Exploring the potential impact of serious games on social learning and stakeholder collaborations for transboundary watershed management of the St. Lawrence River Basin. Water, 8(175).

Parés, M., \& March, H. (2013). Short guides for citizen participation. 3: Guide to evaluating participatory processes. Barcelona: Department of Governance and Institutional Relations.

Parham, D., Parham, T., \& Chang, C. (2011). Neighborland. New Orleans.

Poplin, A. (2012). Playful public participation in urban planning: A case study for online serious games. Computers, Environment and Urban Systems, 36(3), 195-206.

Poplin, A. (2014). Digital serious game for urban planning: "B3-Design your Marketplace!". Environment and Planning B: Planning and Design, 41, 493-511.

Prandi, C., Roccetti, M., Salomoni, P., Nisi, V., \& Jardim Nunes, N. (2017). Fighting exclusion: A multimedia mobile app with zombies and maps as a medium for civic engagement and design. Journal Multimedia Tools and Applications, 76(4), 4951-4979.

Raphael, C., Bachen, C., Lynn, K.-M., Balwin-Philippi, J., \& McKee, K. A. (2010). Games for civic learning: A conceptual framework and agenda for research and design. Games and Culture, 5(2), 199-235.

Robertson, M. (2010). Hide\&Seek: Inventing new kinds of play. Retrieved www.hideandseek.net/2010/10/ $06 /$ cant-play-wont-play

Rowe, G., \& Frewer, L. J. (2000). Public participation methods: A framework for evaluation. Science, Technology, \& Human Values, 25(1), 3-29.

Salen, K., \& Zimmerman, E. (2004). Rules of play. Game design fundamentals. Cambridge, MA: MIT Press.

Sandercock, L. (1994). Citizen participation: The new conservatism. In W. Sarkissian \& D. Perglut (Eds.), The community participation handbook: Resources for public involvement in the planning process (2nd ed., pp. 7-16). Murdoch: Institute for Science and Technology Policy.

Scholz, R. W., \& Tietje, O. (2002). Embedded case study methods integrating quantitative and qualitative knowledge. Thousand Oaks: Sage.

Shaffer, D. W., Squire, K. R., Halverson, R., \& Gee, J.
P. (2005). Video games and the future of learning (WCER Working Paper No. 2005-4). Madison: Wisconsin Center for Education Research, School of Education, University of Wisconsin.

Shipley, R., \& Utz, S. (2012). Making it count: A review of the value and techniques for public consultation. Journal of Planning Literature, 27(1), 22-42.

Skocpol, T. (1997). The Tocqueville problem: Civic engagement in American democracy. Social Science History, 21(4), 455-479.

Tan, E. (2014). Negotiation and design for the selforganizing city. Delft: TU Delft.

Tolmie, P., Chamberlain, A., \& Benford, S. (2014). Designing for reportability: Sustainable gamification, public engagement, and promoting environmental debate. Personal and Ubiquitous Computing, 18(7), 1763-1774.

Tonkens, E. (2014, November 2). De participatiesamenleving inhumaan? De Humanistish Verbond. Rerieved from www.humanistischverbond.nl/nieuws/departicipatiesamenleving-inhumaan

Tufekci, Z., \& Wilson, C. (2012). Social media and the decision to participate in political protest: Observations from Tahrir Square. Journal of Communication, 62(2), 363-379.

Uitermark, J., \& Duyvendak, J. (2008). Citizen participation in a mediated age: Neighbourhood governance in The Netherlands. International Journal of Urban and Regional Research, 32(1), 114-134.

van Bueren, E., Mayer, I., Bots, P., \& Seijdel, R. (2007). The DuBes game. TU Delft.

Wendel, V., \& Konert, J. (2016). Multiplayer serious games. In R. Dörner, S. Göbel, W. Effelsberg, \& J. Wiemeyer (Eds.), Serious games. Foundations, concepts and practice (pp. 211-241). Springer International Publishing.

Whitton, N. (2011). Encouraging engagement in gamebased learning. International Journal of Game-based Learning, 1, 75-84.

Yang, K., \& Callahan, K. (2007). Citizen involvement efforts and bureaucratic responsiveness: Participatory values, stakeholder pressures, and administrative practicality. Public Administration Review, 67(7), 249-264. doi:10.1111/j.1540-6210.2007.00711.x

Yin, R. K. (2013). Case study research: Design and methods (5th ed.). Thousand Oaks: Sage.

Zichermann, G., \& Cunningham, C. (2011). Gamification by design: Implementing game mechanics in web and mobile apps. Sebastopol, CA: O'Reilly Media.

\section{About the Authors}

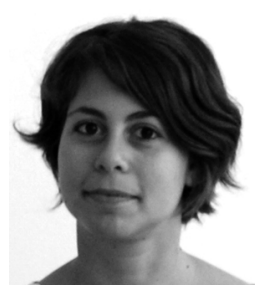

Cristina Ampatzidou is a PhD Researcher at the University of Groningen on the topic of gaming and urban complexity, as well as being a founder of Amateur Cities. Her research investigates the affordances of new media for collaborative city making. She has previously worked as a researcher at the University of Amsterdam, and a guest teacher at TU Delft. Cristina has been a collaborator of Play the City! Foundation and the Architecture Film Festival of Rotterdam, and is a regular contributor to architecture and urbanism magazines. 


\section{COGITATIO}
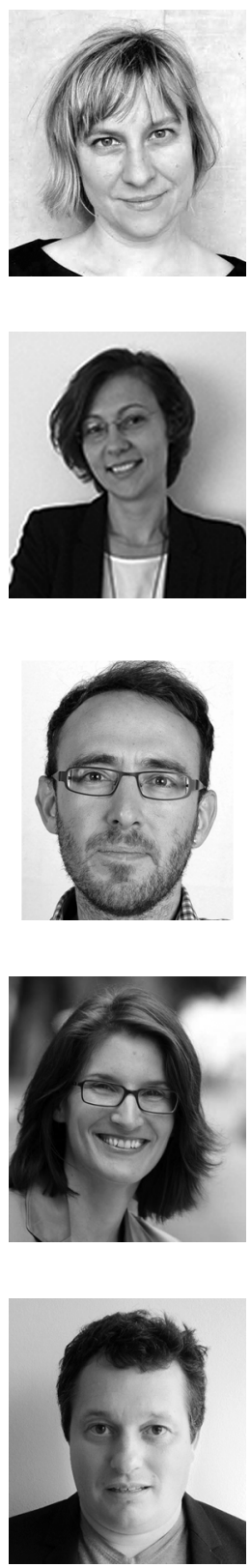

Katharina Gugerell is Assistant Professor in Planning and Spatial Design at the Department of Spatial Planning and Environment, University of Groningen, The Netherlands. Current research topics include Living Labs as experimental forms of governance, games and playful approaches in planning, and power-dimensions in governance networks. She teaches at universities in the Netherlands, Austria, and China.

Teodora Constantinescu is an Architect and Urban Designer with a Master's degree from the Catholic University of Leuven, Belgium. As of 2014, she is a researcher within the Spatial Capacity Building research group at Hasselt University, Belgium. She explores themes such as spatial capacity building, spaces of urban migration, digital social innovation, urban games, and spaces of multicultural microeconomies. Her research topic focuses on the role games play in re-valuing spaces for work.

Oswald Devisch is an Associate Professor in Urban Design at the Faculty of Architecture and Arts, Hasselt University, Belgium. He studied at the Catholic University of Leuven, Belgium and the Bartlett School of Architecture, London, UK. He attained a doctoral degree at the Technical University of Eindhoven, The Netherlands, on spatial simulation models. At Hasselt University, he coordinates the research cluster Spatial Capacity Building exploring themes such as collective learning, casual participation, autonomous transformation processes, and the gamification of participation.

Martina Jauschneg (Dipl.-Ing.) is self-employed directing an office for landscape and open space planning, a Lecturer at the BOKU in Vienna and at the University of Applied Sciences in Salzburg, working in the areas of open space planning, participation and mobility.

Martin Berger (Univ. Prof. Dr.-Ing.) is a Professor of Transport Planning at the Vienna University of Technology. His areas of work include mobility research, municipal and regional transport planning, mobility surveys, and mobility management. 